\title{
シアン浴からの $\mathrm{Ag}-\mathrm{Zn}$ 合金電着物の表面形態に対する 電解電流波形の効果
}

\author{
加来久幸*，原 賢治*，八百周作*，福島久哲**，東 敬**
Effects of Applied Current Wave Forms on The Surface Appearance of The Electrodeposited Ag-Zn Alloys from Cyanide Bath

\author{
Hisayuki KAKU*, Kenji HARA*, Shusaku YAO*, Hisaaki FUKUSHIMA**, Kei HIGASHI**
}

\begin{abstract}
Scanning electron microscopic studies were carried out in connection with the surface appearance of the $\mathrm{Ag}-\mathrm{Zn}$ alloys electrodeposited from cyanide bath with various kinds of current forms. In the direct current plating, the needle-like deposits were obtained at lower current densities, which changed to granular in shape at higher current densities. In the pulsed current plating at on-time/off-time ratio of 0.25 , the surface appearance of the alloys was similar to that obtained with direct current at the same alloy composition. Significant alteration of the current modulation in the pulsed plating resulted in a change in surface appearance, that is, the smoother deposit was obtained by increasing the pulse off-time. In the periodically reversed current plating at a given average cathodic current density, the rounded granular deposits were obtained, regardless of the pulse cycle and duty of anodic current pulse. The displacement reaction and a chemical or electrochemical dissolution of the deposited metals were estimated to bring about the changes in the surface appearance observed in these periodical electrodeposition by measuring the alloy composition, cathode current efficiency and the depositing potential of the alloys.
\end{abstract}

\section{1. 緒言}

一般に, on-off パルス電解 (以下パルス電解と略す) や周期的反転電流電解法 (以下 PR 法電解と略す) によ って電着物表面の平滑化や有孔度の減少など, 電着物の 物性を向上できることが数多〈報告されている1) 5)。こ れらの効果は単一金属の電着物に対してばかりでなく, $\mathrm{Ag}-\mathrm{Sn}^{6)}$ や $\mathrm{Ag}-\mathrm{Cu}^{7)}$ などの 合金電着物について子認め られている。しかしながら，シアン浴からの $\mathrm{Ag}-\mathrm{Zn}$ 合 金電着に拈いてはパルス電解や PR 法電解を適用して も, 肉眼で見る限り電着物の外観は改良されず， $\mathrm{Zn}$ 含 有率が高い場合には直流電解と同じく兏色で無光沢の電 着物しか得られなかった8。。そこで, 本研究では走査型 電子顕微鏡による電着物表面の 観察をもとに, $\mathrm{Ag}-\mathrm{Zn}$ 合金電着物の表面形態汉ぼすパルス電解や PR 法電解 の効果を微視的な観点から調べた。また，パルス電解時 の電位特よび電着物組成々陰極電流効率を比較すること

* 侏安川電機製作所開発研究所 ( $\mathbf{T} 812$ 北九州市八幡 西区藤田2346)

Research Lab., Yaskawa Electric Mfg. Co., Ltd. (Fujita 2346, Yahata-nishi-ku, Kitakyushu-shi 812)

**九州大学工学部（恧812 福岡市東区箱崎6-10-1)

Fac. of Eng., Kyushu Univ. (10-1, Hakozaki-6 chome, Higashi-ku, Fukuoka-shi 812)
によって，パルス電解の off-time 時に 電着物に生じる 変化についても検討した。

\section{2. 実 験 方 法}

\section{2-1 電着試料の作製}

電着試料の作製方法は前報8) と同様である。すなおち 陰極は $3 \mathrm{~cm} \times 3 \mathrm{~cm}$ の銅板を用い, $\mathrm{PR}$ 法電解の場合のみ 電着に先立って $\mathrm{Ag}$ ストライクめっきを行なった。 $\mathrm{Ag}^{-}$ $\mathrm{Zn}$ 合金電着浴の組成は, $A g C N 8 \mathrm{~g} / l, \mathrm{Zn}(\mathrm{CN})_{2} 100 \mathrm{~g} / l$, $\mathrm{NaCN} 160 \mathrm{~g} / l, \mathrm{NaOH} 100 \mathrm{~g} / l$ と乙, 電解槽括よび電解 電源も前報と同じものを使用して大気開放下で電着を行 なった。電着量は $10 \mathrm{C} / \mathrm{cm}^{2}$ とし, 浴のかくはんはマグ ネチックスターラーを用いて 920rpm の回転数で行なっ た。直流電解では浴のかくはんを行なった場合と行わな い場合について電流密度を0.1 3A/ $\mathrm{dm}^{2}$ の範围で変化さ せた。パルス電解では on-time $0.6 〜 25 \mathrm{~ms}$, off-time を100 400 ms, ピーク電流密度を1 86A/ $\mathrm{dm}^{2}$ まで変化 させた。PR 法電解はカソード電流パルス (ic) とアノー ド電流パルス $\left(i_{a}\right)$ の大きさが等しい条件で, 平均カソー ド電流密度 $\left(\overline{\mathrm{i}}_{\mathrm{c}}\right)$ を $0.4 \mathrm{~A} / \mathrm{dm}^{2}$, パルス繰返し周期を0.5 $500 \mathrm{~ms}$, パルス繰返し周期に占めるアノードパルスの比 率 $\left(\theta^{\prime}{ }_{2} / \theta^{\prime}\right)$ を10〜 40\%の範囲で変化させた。この場合, (1)式が成立する。

$$
\overline{\mathrm{i}}_{\mathrm{c}}=\left(\mathrm{i}_{\mathrm{c}} \cdot \theta^{\prime}{ }_{1}-\mathrm{i}_{\mathrm{a}} \cdot \theta^{\prime}{ }_{2}\right) / \theta^{\prime}
$$


ここで， $0^{\prime}{ }_{1}, \sigma^{\prime}{ }_{2}, \theta^{\prime}$ はそれぞれカソード電流パルスの 幅，アノード霆流パルスの幅乩よびパルス繰返し周期を 示す。(1)式加らかかるように, 平均カソード電流密度が 一定の条件でアノードパルスの比率を変えるためにはピ 一ク電流密度を変化させなければならない。本実験にお。 いては, ピーク電流密度は 0.5 から $2 \mathrm{~A} / \mathrm{dm}^{2}$ の値となっ た。

パルス電解条件による電着物組成の変化の㑯向からす ると，バルス電解に拈いては off-time の間に電着物中 の $\mathrm{Zn}$ 成分と浴中の $\mathrm{Ag}$ 錯イオンとの 膡換が生じている と思われることを前報8に特いて報告した。本実験で は, この確認と off-time 時の電着物の化学溶解につい て調べるために合金浴中でパルス電解条件による陰極電 流效率の变化を調べるとともに，合金浴組成からZn 成 分を除いた $\mathrm{Ag}$ 単独浴中でパルス電解を行い，陰極電流 効率を合金電着の場合と比较した。

\section{2-2 電着合金の分析と観察}

電着後の陚料は水洗後乾燥し, 原子吸光法による組成 分析々走査型電子顕微鏡化よる表面観察を行なった。

\section{2-3 パルス電解時の陰極電位測定}

電位測定用の電解槽には 容量 $250 \mathrm{~m} l$ の 型セルを用 い, 飽和カロメル電極に対する陰極の電位の時間变化を オッシロスコープ上へ描かせた。陰極には $1 \mathrm{~cm} \times 1 \mathrm{~cm}$ の銅板を使用し，陽極には2.5cm × $4 \mathrm{~cm}$ の白金板を使用
した。液のかくはんは電着試料の作製の場合と同じく， マグネチックスターラーを用いて行い, 回転数は620rpm とした。

\section{3. 実験結果および考察}

\section{3-1 直流䉓解}

浴のかくはんを行なった条件で電流密度を種々袋えた 洔に，得られた電着物の代表的な表面形態と組成を図 1 に示す。電着物は条件によっては液のかくはん方向に沿 った条痕やデンドライトを生じて部分的に組成が異なっ ていると思われるものもあったが，電着物組成としては 一試料全体の平均値を用いた。浴のかくはんを行なっ た昜合， $0.2 \mathrm{~A} / \mathrm{dm}^{2}$ まで $\mathrm{Zn}$ を性とんど含有しない白色 の電着物が得られた。これらの析出物の表面には針状結 晶が認められ，その結晶の径と長さは電流密度ととすに 増大した[図 1 (a)，(b)]。電流密度が 0.3A/ $\mathrm{dm}^{2}$ では電着 物には Zn が $7 \%$ 程度含まれるようになり，外観は黄色 がかった灰色となったが，電着物の表面には非常に大き な針状結晶が認められた[図 1 (c)]。この試料について は，大きな針状結晶とそれから成長した小さな針状結晶 の組成が異なることが予想されたので，EPMAを用いて $\mathrm{Ag}$ とZnの分有を調べたが，いずれにおいてす $\mathrm{Ag}$ と Znの 偏在はなかったさらに。電流密度を上げると電着物のZn 含有率が上昇し，外観は灰色となった。この時の電着物

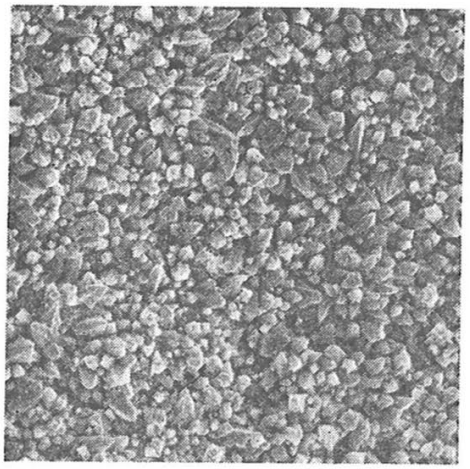

(a) $0.1 \mathrm{~A} / \mathrm{dm}^{2}, \mathrm{Zn} 0.1 \%$

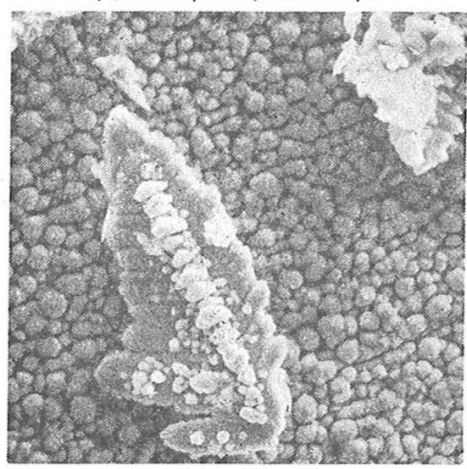

(d) $0.6 \mathrm{~A} / \mathrm{dm}^{2}, \mathrm{Zn} 23.4 \%$

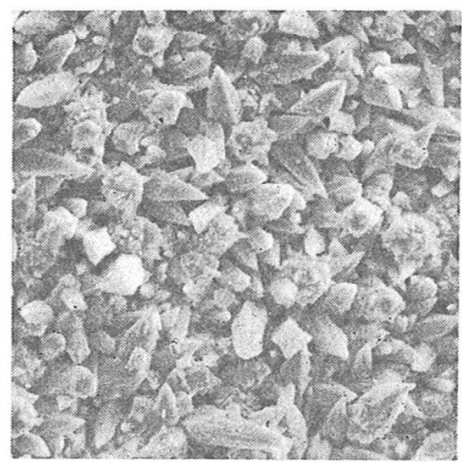

(b) $0.2 \mathrm{~A} / \mathrm{dm}^{2}, \mathrm{Zn} 0.2 \%$

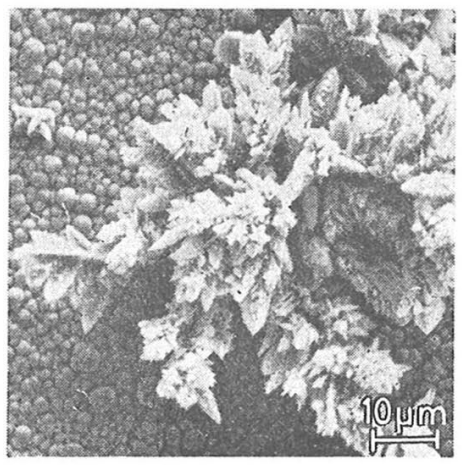

(e) $1.5 \mathrm{~A} / \mathrm{dm}^{2}, \mathrm{Zn} 42.7 \%$

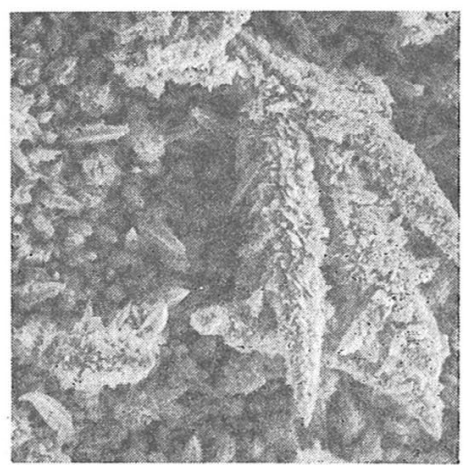

(c) $0.3 \mathrm{~A} / \mathrm{dm}^{2}, \mathrm{Zn} 6.8 \%$

Fig. 1 Surface appearance of electrodeposited $\mathrm{Ag}-\mathrm{Zn}$ alloys from agitated bath with direct current and amount of Zinc containing in the electrodeposits 
の表面には針状結晶は認められなくなり，图 1 (d)の素地 部分に見られるよらな粒状の析出物が生じた。電流密度 が盲くなると，かくはんによって液が当たる側の試料面 に黒色のデンドライトが生成し[図 1，(d)]，このデンド ライトは電流密度とともに成長が著しくなり，発生数も 增加した[図 1 (e)］。素地部分の粒状結晶は， $0.6 \mathrm{~A} / \mathrm{dm}^{2}$ から $3 \mathrm{~A} / \mathrm{dm}^{2}(\mathrm{Zn}$ 含有率 $55 \%)$ 委で電流密度を上けたも 形状汇変化は認められなかった。

浴のかくはんを行わなかった場合の電着物の表面形態 は，Zn 含有率が同じであればかくはん浴から得られた 当のと変わらなかった。なお，かくはん浴からは Zn 含 有率が最大55\%の䉓着物しか得られなかったのに対し， 無かくはん浴からは Zn 含有策が最大69\%までのbのが 得られたが，電着物の表面形態は Zn 含有率が $40 \%$ 程度 のものから60\%を越えるるのまでほとんど変化せず，図 1 ( られた。

\section{3-2 パルス電解}

パルス電解に拉いては, on-time $25 \mathrm{~ms}$, off-time 100 $\mathrm{ms}$ 標準条件とした。この条件で得られた電着物の表 面形態は，Zn 含有率が 同程度であれば面流電解で得ら れたものとほとんど変わらなかった[図 1 (a) と図 2 (a)]。 一方，以下に示すように得られた電着物の $Z n$ 含有率が 同じであってる，パルス条件が大きく翼なる㐞合には析 出物の表面形態が変化した。図 2 と図 3 にはかくはん条 件下で平均電流密度をほぽ同じ条件とし，パルス条件を 変文た場合に得られた電着物の表面形態を示す。この場 合の平均電流密度 $(\bar{i})$ は(2)式で示される。

$$
\overline{\mathrm{i}}=\mathrm{i}_{\mathrm{p}} \cdot\left(\theta_{1} / \theta\right) \text {. }
$$

ここで，i $\mathrm{i}_{\mathrm{p}}$ はピーク電流密度， $\theta_{1}, \theta$ はとれぞれ電流パ ルスの幅とパルス繰返し周期を示す。

图 2 は平均電流密度が約 $0.2 \mathrm{~A} / \mathrm{dm}^{2}$ の条件で得られた Zn 含有率が低く，純銀に近い電着物の表面形獎を示す が, (a)から(c)へと off-time に対する on-time の比が小 さく、ピーク電流密度が大きくなるほど析出物の結晶の 角が取れて洕らかとなっているのがわかる。図了は平均

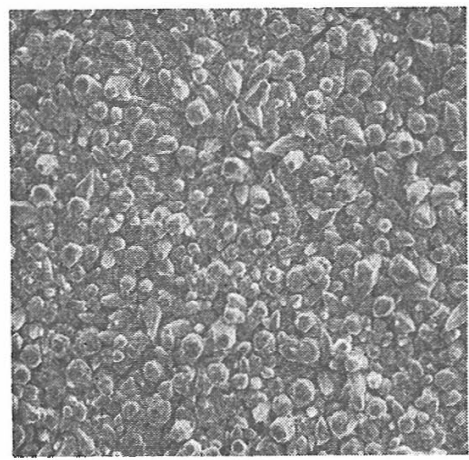

(a) $\mathrm{Zn} 0.6 \%$ (on-time/off-time $\Rightarrow$ ) $25 \mathrm{~ms} / 100 \mathrm{~ms}^{\mathrm{i}} \mathrm{i}_{\mathrm{p}}=1 \mathrm{~A} / \mathrm{dm}^{2}$

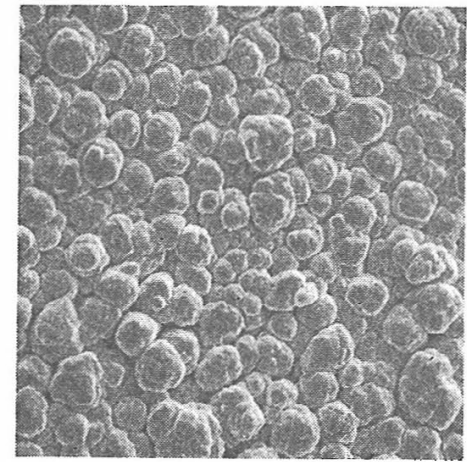

(b) $\mathrm{Zn} 0.3 \% 25 \mathrm{~ms} / 400 \mathrm{~ms}$ $\mathrm{i}_{\mathrm{p}}=4 \mathrm{~A} / \mathrm{dm}^{2}$

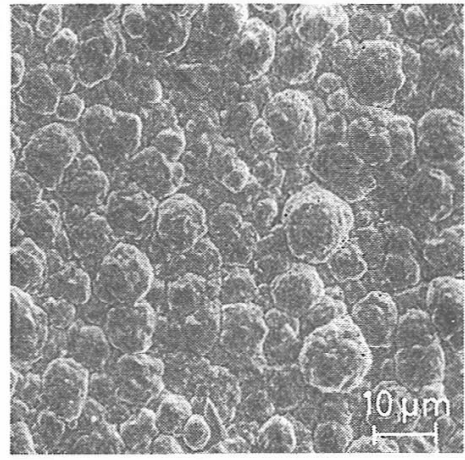

(c) $\mathrm{Zn} 0.2 \% 1 \mathrm{~ms} / 100 \mathrm{~ms}$ $\mathrm{i}_{\mathrm{p}}=20 \mathrm{~A} / \mathrm{dm}^{2}$

Fig. 2 Surface appearance of $\mathrm{Ag}-\mathrm{Zn}$ alloys obtained from agitated bath with pulsed current at average current density of $0.2 \mathrm{~A} / \mathrm{dm}^{2}$.

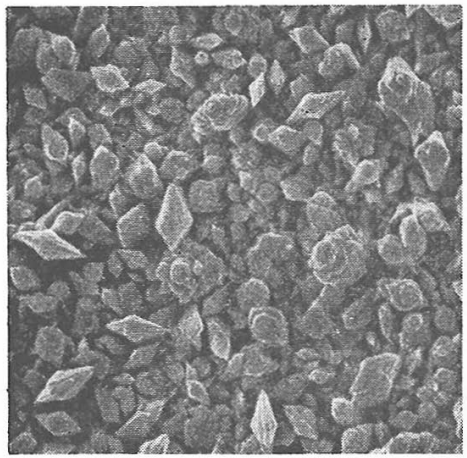

(a) Zn $9.1 \%$ (on-time/off-time $=$ ) $25 \mathrm{~ms} / 200 \mathrm{~ms} \quad i_{p}=4 \mathrm{~A} / \mathrm{dm}^{2}$

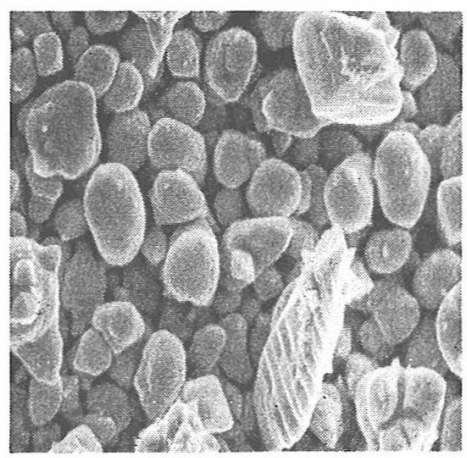

(b) $\mathrm{Zn} 9.2 \% \quad 1 \mathrm{~ms} / 100 \mathrm{~ms}$ $\mathrm{i}_{\mathrm{p}}=50 \mathrm{~A} / \mathrm{dm}^{2}$

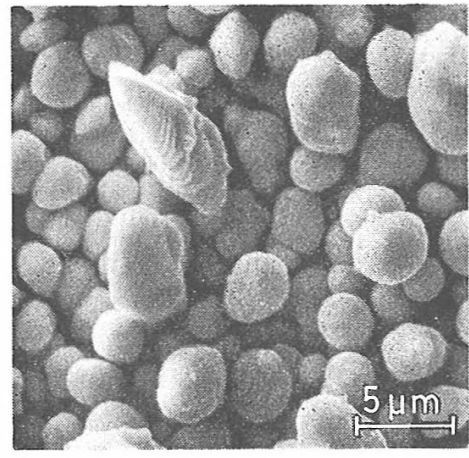

(c) $\mathrm{Zn} 11.1 \% \quad 0.6 \mathrm{~ms} / 100 \mathrm{~ms}$ $\mathrm{i}_{\mathrm{p}}=86 \mathrm{~A} / \mathrm{dm}^{2}$

Fig. 3 Surface appearance of $\mathrm{Ag}-\mathrm{Zn}$ alloys obtained from agitated bath with pulsed current at average current density of $0.5 \mathrm{~A} / \mathrm{dm}^{2}$. 
Table 1 Cathode current efficiency and the depositing potential for pulsed current plating.

\begin{tabular}{|c|c|c|c|c|c|c|}
\hline \multirow{2}{*}{$\begin{array}{l}\mathrm{Zn} \text { in } \\
\text { deposit } \\
(\text { wt } \%)\end{array}$} & \multirow{2}{*}{$\begin{array}{l}\text { Peak } \\
\text { current } \\
\text { density } \\
\left(\mathrm{A} / \mathrm{dm}^{2}\right)\end{array}$} & \multirow{2}{*}{$\begin{array}{l}\mathrm{On}^{-} / \\
\text {Off-time } \\
\quad(\mathrm{ms})\end{array}$} & \multirow{2}{*}{$\begin{array}{l}\text { Average } \\
\text { current } \\
\text { density } \\
\left(\mathrm{A} / \mathrm{dm}^{2}\right)\end{array}$} & \multirow{2}{*}{$\begin{array}{l}\text { Cathode } \\
\text { current } \\
\text { efficiency } \\
(\%)\end{array}$} & \multicolumn{2}{|c|}{$\begin{array}{l}\text { Electrode (V vs SCE) } \\
\text { potential }\end{array}$} \\
\hline & & & & & E off-time & E on-time \\
\hline 06 & 1 & $25 / 100$ & 020 & 99.5 & -095 & -1.43 \\
\hline 03 & 4 & $25 / 400$ & 024 & 916 & -090 & -162 \\
\hline 02 & 20 & $1 / 100$ & 020 & 891 & -099 & $\begin{array}{ll}-1 & 71\end{array}$ \\
\hline 91 & 4 & $25 / 200$ & 044 & 917 & -108 & -166 \\
\hline 92 & 50 & $1 / 100$ & 050 & 871 & $\begin{array}{ll}-1 & 13\end{array}$ & -216 \\
\hline 111 & 86 & $06 / 100$ & 051 & 878 & $-1 \quad 15$ & -218 \\
\hline
\end{tabular}

電流密度を約 $0.5 \mathrm{~A} / \mathrm{dm}^{2}$ とした時に 得られた $\mathrm{Zn}$ 含有率 約10\%の電着物の表面形態を示す。この場合も on-time/ off-timeの值が小さく，ピーク電流密度が大きくなるほ ど針状の析出物の結晶が丸くなって和り，析出物が溶解 てているように見える。

シアン浴からの $\mathrm{Ag}-\mathrm{Zn}$ 合金の析出は 規則型析出であ って, Ag の析出が桩散支配となる 状況下で Zn の析出 が起こること，执よびこの合金析出の機構がパルス電解 や PR 法電解に特いても変化しないことを既に報告し た ${ }^{8)}$ 。のような合金析出の機構が成立しているとする そ, $\mathrm{Ag}-\mathrm{Zn}$ 合金電着物中の $\mathrm{Zn}$ 含有率は電着が行われて いる電位が卑になるほど高くなると考えられる。そこ で，パルス電解に扣いて実際に電着が行われている電位 をオッシロスコープを用いて測定し，その電位から尒想 される電着物組成と電解後に得られた電着物の組成とを 比較することにより，上記のような off-time 時に搁け る電着物の変化について以下検討した。

表 1 には図 2,3 亿示した電着物の陰極電流効率特よ び電着時の電位を示す。電着時の電位 E on-time は電 流パルスの立下り直前の電位からオーム損による電位降 下分を除いた電位であり，E off-time は電流パルス立 上り直前の電位である。平均電流密度が同じであって ઇ, 実際に電着が起こっている電位 (E on-time)はピー ク電流密度が大きくなるほど卑になっている。この電位 の移行はピーク電流密度が大きい場合, 一部濃度過電圧 の増加分を含むが，ピーク電流密度の増大に伴い $Z \mathrm{n}$ 析 出の過電圧も増大すると考它られ, 合金の $\mathrm{Zn}$ 舍有率は 高くなると予想される。ところが実際に得られた電着物 は, 平均電流密度が同じ場合には至ぼ同じ組成となっ た。これは $\mathrm{Ag}$ に比べて卑な金属である電着物中の $\mathrm{Zn}$ が off-time の間に浴中の Ag 錯イオン括よび溶存酸素 の還元をカソード反応して酸化溶解すると考えれば理解 できる。また同じ平均電流密度での陰極電流効率は, on-time/off-time 比が小さく（従ってピーク電流密度が 大きく）なる泀ど低下している。これは電極電位がより 卑になるほど水素ガスの発生が著しくなることも原因の

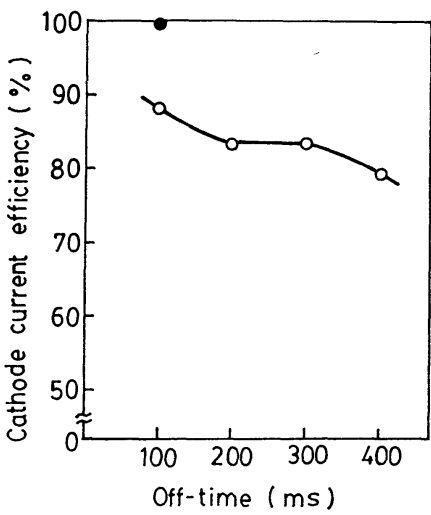

Fig. 4 Effect of off-time on the cathode current efficiency for the electrodeposition of silver.

Peak current density : $1 \mathrm{~A} / \mathrm{dm}^{2}$, agitated. $\bigcirc$ : silver deposition. : silver-zinc alloy deposition.

一つと考光られるが，一方では析出した Agが浴中へ化 学溶解したためとも考えられるので， $\mathrm{Ag}$ 単独浴を用い てこの効果を調べた。

$\mathrm{Ag}$ 単独浴でピーク電流密度を $1 \mathrm{~A} / \mathrm{dm}^{2}$, on-time を25 $\mathrm{ms}$ 一定とし， off-time を100〜400ms の範团で変化さ せた時の陰極電流効率の変化を図 4 亿示す。 $\mathrm{Ag}$ 単独浴 においても off-time が長くなるほど陰極電流効率は低 くなった。 off-time が長くなるほど on-time 時に陰極 近傍で生じた Ag イオン濃度の減少が回復される効果が 大きいと考えられるので，この結果は一度析出した $\mathrm{Ag}$ が off-time の間に 化学溶解することを示している。こ れより，Ag-Zn 合金電着物に拈いて on-time/off-time 比が小さい葟ど析出物が丸くなっていたのは, off-time の間に析出物の化学溶解拉よび $\mathrm{Ag}$ の置換析出が生じた ためであると考学られるまた図 4 中の黒丸は, Ag 単 独浴と同一のパルス電解条件で合金浴から得られた電着 物の陰極電流効率を示す。この時得られた電着物の組成 は，Znが0.6\%と核济純銀に近いものであったので， これと Ag 単独浴で得られた電着物の陰極電流効率の差 
（約 $10 \%)$ は off-time 時に批ける $\mathrm{Zn}$ 成分と $\mathrm{Ag}$ 錯イオ ンとの置換の程度を示するのと考光られる。このように パルス電解の off-time 時怔電着物中の 早金属成分方 中の貴金属イオンと嚂換したり，析出物が化学溶解する そいう現象は, Ag-Sn 合金のパルスめっぎ3やシフン浴 からのAuのパルスめっきのの際にる認められることが 報告されている。

\section{3-3 PR 法電解}

PR 洗電解は，パルス電解で諗められた off-time 時に 牤りる電着物の化学溶解の代わりにアノード電流パルス を加兄て析出物をアノード溶解し，これによって電着物 表面を平滑化することを目的として Ag-Zn 合金電着へ 適用したものである。图 5(a)k PR 法電解で得られた電 着物の表面形態を示す。PR 法電解に打いては, 平均力 ソード電流密度が 同じであれば，パルス繰返し周期や パルス繰返し周期に対するアノード電流パルスの比率 $\left(\theta_{2}^{\prime} / \theta^{\prime}\right)$ を变化させても電着物組成がほとんど変化しな いことはすでに報告した ${ }^{8)}$ 。 PR 法電解によって得られ た電着物は，表面形態について子組成と同じ傾向を示 L, 平均電流密度が等しい条件であれば，アノード電流 パルス幅の比率を $10 \%$ から $40 \%$ ，パルス繰返し周期を $0.5 \mathrm{~ms}$ から500 ms まで変化させても表面形態は図 $5(\mathrm{a})$ と 同様で，小さな粒状の析出物と大きな球状の析出物が認 められた。るた图 5 には PR 法電解で得られた電着物と ほ注同じ $Z n$ 含有率を有する直流電解とパルス電解で得 られた電着物の表面形熊を比較のために示す。前述のよ ろに, on-time/off-time 此が0.25となるパルス電解条 件で得られた電着物の表面形態は，電着物中 $\mathrm{Zn}$ の含有 率が同じであれば直流電解と変わらない。しかしなが ら, PR法電解で得られた電着物には, 直流電解やパルス 電解と似た形状を有する小さな粒状析出物の他にアノー
ド溶解して丸くなったような析出物が数多く存在してい る。このように微視的に観察すれば，アノード電流パル スによって析出物を溶解するという試みに対する効果は かったことになるが，肉眼による観察では，PR 法電解 で得られた電着物も直流電解やパルス電解で得られた電 着物も，Zn含有率が同じならば外钼は同じであった。 これより，アノード電流パルスやパルス電解が電着物の 表面形態に及ぼす效果は，肉眼で判別できるほどには大 きくないと言える。

\section{4. 結票}

直流電解とパルス電解および PR 法電解によってシナ ン浴加ら得られた $\mathrm{Ag}-\mathrm{Zn}$ 合金電着物の 表面を走查型電 子湿徽鏡を用いて観察し，電着物の表面形態に及ぽすパ ルス電解や PR 法電解の効果について微視的な観点から 調ベた。またパルス電解時の電位および電着物組成之陰 極電流効率を比較することによって，パルス電解の offtimeの間海電着物炕生じる変化について調べた。

直流電解で得られた $\mathrm{Ag}-\mathrm{Zn}$ 合金電着物の表面には $\mathrm{Zn}$ 含有率が $10 \%$ では大きな針状結昆, それ以上の $\mathrm{Zn}$ 含 有察では粒状の析出物とデンドライトが認められる。パ ルス電解 (on-time/off-time $=0.25$ ) で得られた電着物 の表面形態は， $Z n$ 含有率が 同じ場合には值流電解で得 られたものと変わらないが，on-time/off-time 比を小 さく（ピーク電流密度を大きくすするぼ， off-time 時 に電着物中の $\mathrm{Zn}$ 成分之浴中の $\mathrm{Ag}$ 錯イオンとの置換や 析出物の化学溶解が進行する。平均カソード電流密度が 等しい条件の PR 法電解によって得られた電着物恃，ハ ルス繰返し周期やアノード電流パルス愊の比率によら ずほほぼ同じような表面形態を示す。直流電解やハルス 電解で得られた組成の等しい電着物と比胶すると，PR

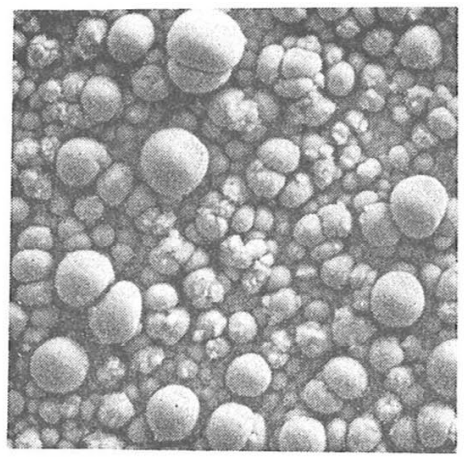

(a) PR plating $\mathrm{Zn} 47.8 \%$ anodic pulse/cathodic pulse $=1 \mathrm{~ms} / 4 \mathrm{~ms}$

$\overline{\mathrm{i}}_{\mathrm{c}}=0.4 \mathrm{~A} / \mathrm{dm}^{2}$ $i_{c}=i_{\Omega}=0.67 \mathrm{~A} / \mathrm{dm}^{2}$

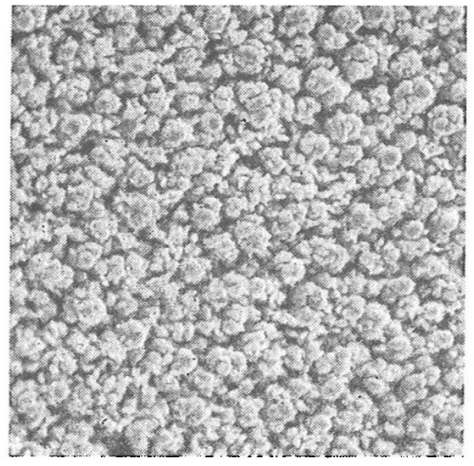

(b) DC plating $\mathrm{Zn} 47.3 \%$

$0.3 \mathrm{~A} / \mathrm{dm}^{2}$

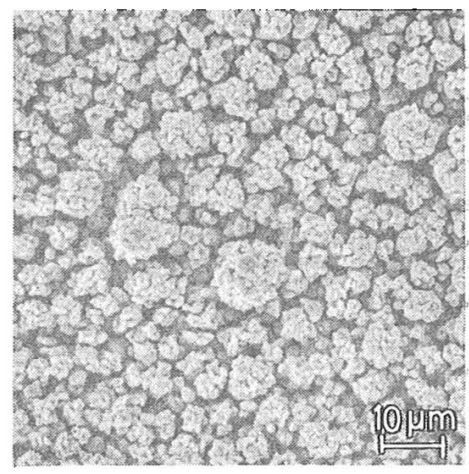

(c) PC plating $\mathrm{Zn} 39.9 \%$ on-time $/$ off-time $=25 \mathrm{~ms} / 100 \mathrm{~ms}$. $\overline{\mathrm{i}}=0.4 \mathrm{~A} / \mathrm{dm}^{2}$ $i_{p}=2.0 \mathrm{~A} / \mathrm{dm}^{2}$

Fig. 5 Change in the surface appearance of $\mathrm{Ag}-\mathrm{Zn}$ alloys obtained from quiescent bath with various kinds of current. 
法電解で得られた電着物にはアノード溶解によって丸く なったような析出物が数多く認められる。微視的に観察 すると, パルス電解や PR 法電解によって電着物の表面 形態に変化を生じるが，この変化は肉眼で判別できる汪 どには大きくない。

$$
\text { (1982-2-8 受理) }
$$

（昭和55年 5 月, 本協会第61回学術講演大会拉よび昭和 56年 3 月, 本協会第63回学術講演大会にて発表)

本論文中の非S I 単位のS I 単位に対する換算表

\begin{tabular}{lr|c|c}
\hline \multicolumn{2}{c|}{ 量 } & 単位記号 & S I 単位による值 \\
\hline 容 & 量 & $\mathrm{m} l$ & $1 \mathrm{~m} l=10^{-6} \mathrm{~m}^{3}$ \\
濃 & 度 & $\mathrm{g} / l$ & $1 \mathrm{~g} / l=1 \mathrm{~kg} / \mathrm{m}^{3}$ \\
\multicolumn{2}{l|}{ 電流密度 } & $\mathrm{A} / \mathrm{dm}^{2}$ & $1 \mathrm{~A} / \mathrm{dm}^{2}=10^{2} \mathrm{~A} / \mathrm{m}^{2}$ \\
\hline
\end{tabular}

文 献

1) N.Ibl, J.C.Puippe, H.Angerer ; Electrocrystallization in Pulse Electrolysis, Surf. Technol., 6, 287 (1978)

2) P.C. Andricacos, H.Y.Cheh, H.B.Linford ; Application of Pulsed Plating Techniques to Metal
Deposition, Plat. Surf. Finish., [9], 44 (1977)

3) C.C. Wan, H.Y. Cheh, H.B. Linford ; The Application of Pulsed Plating Techniques to Metal Deposition, Plating, [6], 559 (1974)

4) ラム・チュー・ラン, 大野 泳, 佐治 孝, 春山志 郎; 酸性浴に拈けるすずのパルスめっき，本誌，32, 64 (1981)

5）福本幸男, 北西弘幸, 林 忠夫; パルス電解法によ る銀の電析反応, 本誌, 32, 302 (1981)

6) H. Leidheiser Jr., A.R.P. Ghuman ; Pulse Electroplating of Silver-Tin Alloys and the Formation of $\mathrm{Ag}_{3} \mathrm{Sn}$, J. Electrochem. Soc., 120, 484 (1973)

7 ) 丹野益男, 鈴木 隆; 銀一銅合金メッキ法, 公開特 許公報，昭54-141346

8 ）加来久幸, 原 賢治, 八百周作, 福島久哲, 東 敬; シアン浴からの $\mathrm{Ag}-\mathrm{Zn}$ 合金の析出挙動, 本誌, 33, [11] 562 (1982)

9) H.Y. Cheh ; Electrodeposition of Gold by Pulsed Current, J. Electrochem.Soc., 118, 551 (1971) 